\title{
A letter from Jack Horner
}

Some experiences and thoughts on continuity of cultural knowledge and language among Aboriginal people in Northern New South Wales (1930-1960s), related in a letter to Aboriginal History.

Jack Horner

It is conventional to say that the indigenous people in New South Wales bore the brunt of the British colonists' invasion in the nineteenth century. Yet, though the clans dispersed, and initiations withered and died, some of the 'classical' culture remained in rural pockets of the State. A strong reason why this was so, why conservative values continued a cultural knowledge despite the external pressure to move elsewhere, was the general communal need for security in land ownership. Throughout the years that I was Honorary Secretary of the Aboriginal-Australian Fellowship in Sydney (1958-1966), the NSW Aborigines Welfare Board kept up a constant insistence that boundaries of local reserves might change. Farmers nearby would be willing to buy, and the reserve residents could never be sure that some portion of their 'home' would remain as their land.

The arbitrary nature of these boundary shifts may be shown by one that produced unexpected allies for the Bundjalung people. In about 1954, an experienced primary school teacher named Rus McCrohon came to the AWB school at Cabbage Tree Island, Richmond River. He was determined to improve the children's morale and raise their interest in reading and writing. He was soon having heated rows with the conservative Manager. While searching one day among high grass for a 'lost' cricket pitch, Rus was interrupted by a jeering Manager, who said, 'Don't worry too much about the wicket. The Welfare Board will sell this half of the Island, in three months'. Enraged, McCrohon won the interest of Ballina business men to raise funds for a Society, to buy back the disputed land for people on Cabbage Tree Island. This story came to the Anglican Bishop of Grafton, K.J. Clements. He met McCrohon and then invited the founder of Tranby Aboriginal Co-operative College, socialist and priest Father Alf Clint, to discuss with McCrohon and Bob Bolt a possible way for cane cutting to finance a Co-Op. Store.

Some languages were alive in mid-nineteenth century New South Wales. I stayed at Dr Charles Duguid's home in Adelaide in 1962 for a FCAATSI conference (he was the President). He told me that in 1937 he had met in Oxford the famous Greek scholar Gilbert Murray, who related a story that in 1867 his father, the grazier-politician Sir Terence Murray, had taken with him to the Paris Exposition two Wiradjuri (or possibly Ngunnawal) station servants. Within a fortnight of their stay in Paris, the two Aborigines had picked up spoken French conversation. They had, of course, 
encountered strange languages at home. As Gilbert Murray was born in Sydney in 1866, this account of vitality in local languages would have come from Sir Terence himself.

Another source for our awareness of spoken language comes from the feminist Jessie Street, who recalled that as a girl living with her Lillingston family at Yulgilbar cattle station on the Clarence in the late 1890s, she heard an Ogilvie aunt teaching English to a class of boys and girls from Baryulgil, Bundjalung people. This implies that the Bundjalung dialect was still spoken. Her grandfather Edward Ogilvie had learned their dialect and befriended them. The local people led the procession at his burial in 1896. In the early 1930s one of the Yeigir at Maclean, a woman known to whites as Rosie Combo, in old age was enlightening the social anthropologist Radcliffe-Brown on the language of her people, among other things. Kinship was his special interest.

An instance of bush resourcefulness in Koori tradition appears in a book by Alex $S$. Gaddes, Red Cedars, Our Heritage. A 'clever man' named Dottai living with his clan at Bowraville in 1885 saved the leg of a horsebreaker (the author's father). The leg had been fractured twice when the horse crashed into a tree. This accident happened at Taylor's Arm, a branch of the Nambucca River. Dottai made a platform in a tree-fork. As a 'clever man' he would have had knowledge of painkilling herbal properties. After setting the leg in splints, he gently lifted the man onto the platform, and with rushes and grass-strings tied the limb to the angled tree branch, forming a traction. The patient was comfortable; Dottai visited him often; the Station family cared for his needs. Dottai's descendant, Tasman Dottai, in 1947 protested for civil rights with Bill Ferguson in Sydney.

In 1935 a Kamilaraay man Herbert Groves (handyman at his home reserve, Caroona near Quirindi) had joined the New South Wales Aborigines Protection Board staff, at the suggestion of William Ferguson, to sample living conditions on segregated reserves. From August that year to May 1936, the APB sent Groves to Angledool to help staff tend the sick. He saw a genuine and violent stick fight between two men, each holding a shield. When describing this event for me in 1957, Groves was still shocked at the violence, though he added; 'Mrs Clarke, the Manager's wife, of Maori descent herself, quietly moved about, picking up the sticks.'

Baryulgil on the Clarence River was an isolated settlement in the 1930s. The U.A.M. missionaries based at Lismore, Mr and Mrs Tinsley, travelled by car, via Grafton, crossing the Richmond Range over dirt tracks. In April 1934, Tinsley reported to the United Aborigines Messenger that eleven huts housed 180 people, with another three houses (evidently owned by white people) beside the Clarence. 'The men who work are away most of the week'; 'they assemble at the camp Saturday and Sunday. Ration day comes once a fortnight', Tinsley wrote prior to the (1948) opening of the asbestos mine. The following year, his report (March 1, 1935) after moaning a lot about the resistance to his fundamentalist services, described his new experience of Aboriginal dance:

On the night of the 2nd instant (February 1935), I saw a corroboree for the first time.... The ones who were not taking part sat around and kept up a weird but fascinating chant in their own language. It was an impressive sight and a new experience... When the ration runs out, they can sometimes make a little by washing gold, or hunt the kangaroos upon the hills round about... 
Edward Ogilvie of Yulgilbar station had bequeathed to the people some land on the property for their exclusive ownership and use; it was known as 'The Square' and as such was referred to me, after the Fellowship 1961 conference when Kooris became aware that I had some personal access to politicians in the State Parliament. I was asked to make a request of Jessie Street, whose mother had inherited Yulgilbar Station, if this land still belonged to the people at Baryulgil. In the end, I met Jessie's lawyer son, Sir Laurence Street, and we discussed 'The Square'. The whole property by then had been sold to another squatter company. While friendly in his manner, he held out little hope for taking back the land, which would have been where that 'corroboree' had been performed, on Saturday nights many times.

One reason for the conservation of knowledge and language among Bundjalung speakers was the slowness of change on the large Scots-run cattle-breeding stations, derived from the original Dyraaba Station (Cassino, Tabulam, Kyogle, Runnymede, Wooroowoolgen) which all offered good training and constant work. James Morgan, who held the so-called 'full-blood' Aboriginal position on the Welfare Board from 1964 to 1968 came from this background. He was born in 1902, possibly grandson of 'King' Morgan. Trained as cattle-hand he told me he had 'never lost a day's work'. He and his older relative, Alex Vesper from Kyogle, during the 1920s travelled around seeking rural work when not in the cattle-yards. Fencing was a shilling a post; farmers knocked this down to a mere ninepence. 'We could not argue', said Morgan, 'for we had to have the money. No food at Stoney Gulley.' They kept up many traditional ways. They both knew all the names and legends and revered places of the area. Besides their fishing and hunting (by gun) for food, they built little gunyahs, and 'put a little fire in front of them, very cosy in winter.'

Clive Williams, son of a Casino tracker who was also from the Upper Richmond country, joined them a few years later, and found both men 'reading books from the light of the little camp fires'! In 1919, James Morgan had learnt about reading English language, by answering a Sydney newspaper advertisement for a correspondence course. Clive Williams, more than anyone else, explained vividly for me what it means when a Koori finds he or she is 'outside country'. 'You feel very much alone', he told me. 'The birds, bush, trees and rocks - they don't know you, don't recognise you.' It was evidently a bewildering experience, a sense of loss, rather like a loss of hearing. Kevin Gilbert tried to describe to me how a spirit of companionship and identity is felt 'within country', but I did not comprehend easily. A common knowledge among Kooris, even today, is the familiar 'bird who brings back bad family news.' A Tranby College student from Coffs Harbour in 1965 first revealed this traditional belief to me and it is confirmed for the far South Coast of the State by Eileen Morgan in The Calling of the Spirits.

The strong tradition for families to remain together, and to attend the family funerals was another accepted custom maintained from earlier times. When in August 1960, the Co-op. Store at Cabbage Tree Island officially opened, visitors came from far and wide along the North Coast to celebrate the occasion. Charles Leon (President of the Aboriginal-Australian Fellowship, in Sydney) travelled with me on the Brisbane Express train. I awoke at two a.m. (it had stopped, to 'pick up'), to find Charles standing by the carriage door. 'It's Nambucca - my brother lives here; I thought he might be waiting for me', he explained. As for funerals, all relatives were expected; no excuses were possible. When a Leon family member died suddenly at Wollongong, the people came to the local 
cemetery only to find that the funeral director at Wollongong had not sent the deceased by train; as usual, he wished to be paid fees before he acted. All the journeys were in vain. Naturally, people were very indignant!

Anthropologist, Malcolm Calley, in 1954-55 went to Bundjalung country to listen to the Pentecostal convention held that year at Muli Muli (Woodenbong) and Tabulam. This convention, operating as a baptism ceremony in defiance of authority, was run by Pastor Frank Roberts, senior. He was a fiery rebel who had pursued a long argument with the Lismore City Council over the principle that the people should own Cubawee Reserve in Lismore, or else own land for residence in the city itself. The religious convention drew people from afar, and Calley became aware, as he wrote later in his doctoral thesis (1959) that the church enabled the family groups to meet and create a powerful sign of their traditional family leadership structure as well as a mixed Pentecostal Christian hope and Gidabal expression. A cultural activity in ritual lent the pastor leadership, accepted in the wider white world.

It was recorded by Thomas Hall (Hall, 1987) that the last Bora ceremony held at Killarney (south-east of Warwick, within Gidabal land, but just over the Dividing Range in Queensland) was in 1858. James McGrath once told Roland Robinson that the last dance at Nambucca Heads was in 1924'; Clive Williams complained to me that when a young man, he had 'missed the last initiation ceremony by a few weeks'. These supposed events are now beyond recovery, since they were private. Could someone have misdirected Clive Williams? The dates appear quite late.

At Canberra in 1969 the FCAATSI Conference was to be opened by a Bundjalung Elder, Cecil Taylor, speaking the language. He and Dick Donnelly preserved the Gidabal culture. Prior to the Conference, I took Taylor to the old Institute of Anatomy (now the Film and Sound Archive), where a large display board could be observed through a window. It was Good Friday, and public buildings were closed. The display showed some photographs of Walbiri men dancing, very likely taken by Herbert Basedow, in the 1920s. Taylor took a long look, then suddenly dropped to sit on the verandah floor, crossed his legs, and loudly sang a song. I stood unmoving in tribute, but did not ask him what the song was, for its heartfelt passion was unmistakeable, in Gidabal. Was this a lament that the dancing was over?

The Gidabal dialect was published (Geytenbeek, Aboriginal Studies Press, 1971) as a grammar, and has appeared since as a primer. Near the mouth of the Clarence river, on an island officially pronounced in error as Ulgandahi Island, the two sisters Joyce and Christine Mercy among other youngsters learnt the southern Bundjalung dialect from their older relations. Joyce Clague (born Mercy) has since told me that the island's name, spelled properly, is Ngullagandahi, the nasal sound ' $\mathrm{Ng}$ ' is pronounced, and the name means 'Shaped like an ear'. I would expect that many generations had known this dialect before that of Joyce Clague and her sister Christine Mumbler.

Alex Vesper was evidently regarded as a person holding important links with the past at Stoney Gulley in the 1930s. Stoney Gulley was located near the old Runnymede cattle station homestead, by then taken over by the NSW Aborigines Protection Board, and run as a APB Home. According to my interview in 1966 with James Morgan, Vesper had prevented the APB Inspector (Smithers) from taking away a young girl, Evelyn Webb. In the 1960s the Webb family were living in Redfern, where Evelyn attended 
weekly dances run by the Aboriginal-Australian Fellowship. Today, according to the newspaper Koori Mail (October 1996) she is an Elder in a community near Byron Bay, in Bundjalung country.

Vesper also had a responsibility at Stoney Gully for keeping the land. In 1960, during a break of the FCAATSI Conference held in January that year, at Newport, near Sydney, Vesper spoke to me. He was still angry at the way A.P. Elkin and other Welfare Board members had sent Stoney Gulley people to Muli Muli, Woodenbong, and sold the land to local farmers. 'I should never have allowed them to do that', he said. 'I was responsible for that land'. The Welfare Board's arbitrary action had been taken in 1940, twenty years before.

Living at Woodenbong, Vesper evidently lost the high status that he had enjoyed at Stoney Gulley. He did not belong to the original families of Muli Muli village, and was regarded there as an outsider, though he knew the myths and legends and could recite them to poet Roland Robinson.

Many of the incidents from these conversations may not be easy to present in full detail, let alone verify as truly historical. Far from being unimportant, however, I think that the oral nature of 'thrown-off' observations, though lacking the precise accuracy given by note-taking, may offer some fresh insights. For example, Clive Williams and I were discussing some recent stories of racial discrimination (this was at the entrance to the Cahill Expressway road tunnel in Sydney, near the main public gate to the Botanical Gardens, where he worked in the 1970s), when he ruefully admitted:

'Of course, I was brought up not to trust that Moree mob'.

I was amazed by this remark. 'But Clive, ....!

'I know, I know', he grinned. 'The town Moree is nowhere close to Casino. But that's the way people felt about it at the time.'

Were the 'Moree mob', as Williams described them, sufficiently far away, over the Richmond and New England Ranges, and speaking the strange Kamilaraay tongue, to be dismissed as foreigners, perhaps feared? I have no idea of the motivation for this evident tradition of distrust to understand.

For over thirty years Jack Horner has been active in organisations seeking justice for Aboriginal people, and more recently Reconciliation within Australian society. His contributions were honoured in 1997 by the Anglican Church through the Canberra-Goulburn Diocese. He is the author of the biography of William Ferguson - Vote Ferguson for Aboriginal Freedom. For the Bicentennial volumes Australians: A historical Library, he co-authored the section in Australians 1938 on 'The Day of Mourning' (26th January 1938). He is still actively researching and writing, especially on the 1967 Referendum. His involvement in this event was significant.

\section{References}

For the personalities, places and events discussed in this letter Jack Horner has drawn on his personal memories and notes of interviews with:

Herbert Groves (1958)

Charles Leon (1961) 
James Morgan (1966, n-d)

Pastor Frank Roberts Snr (1960s)

Pastor Frank Roberts Jnr (1960s, 1972)

Clive Williams (Sydney 1965-71).

Further relevant material has been referred to from:

Calle, Malcolm. 1964, 'Pentacostalism among the Bundjalung', In Aborigines Now, $M$. Reay (ed), Angus and Robertson, Sydney, pp. 48-58.

Cohen, Bill. 1987, To my Delight, Aboriginal Studies Press, Canberra.

Goodall, Heather. 1996, Invasion to Embassy, Allen and Unwin, Sydney.

Hall, Thomas. 1987, A Short History of the Downs Blacks known as the Blucher Tribe, Vintage Books, Toowoomba.

Morgan, Eileen. 1994, The Calling of the Spirits, Aboriginal Studies Press, Canberra.

Sakuless, Peter. 1978, Jessie Street: A rewarding but unrewarded life, University of Queensland Press, St. Lucia.

Robinson, Roland. 1977, The Man who Sold his Dreaming, Rigby, Adelaide. 